\title{
EFFECT OF CELERY EXTRACT ON FRUCTOSE INDUCED INSULIN RESISTANCE Rattus norvegicus
}

\author{
Devitya Angielevi Sukarno ${ }^{1,2}$, Arifa Mustika ${ }^{3}$, Purwo Sri Rejeki ${ }^{4,5}$ \\ ${ }^{1}$ Magister Program of Basic Medical Science, Department of Physiology, ${ }^{2}$ Department of Physiology, ${ }^{3}$ Department \\ of Pharmacology, ${ }^{4}$ Department of Physiology, ${ }^{5}$ Sport Medicine Division, Department of Physiology, Faculty of \\ Medicine, Universitas Airlangga, Surabaya, Indonesia
}

\begin{abstract}
Diabetes mellitus (DM) is one of the global health problems and in the top 4th ranks as the main cause of death in developing countries (IDF, 2015). The pathogenesis of type II DM involves abnormalities in insulin secretion and activity that leads to insulin resistance. This research aims to study the efficacy of celery (Apium graveolens) as a prevention of insulin resistance. In this study, the samples were 45 Wistar rats (Rattus norvegicus), male sex, aged 4-6 weeks, weight 150-175 grams, and had normal fasting blood glucose levels by tested before treatment. The experimental animals were divided into 5 groups, K1 was negative control group (insulin resistance by given $20 \%$ fructose 1,86 $\mathrm{g} / \mathrm{kg} \mathrm{BW} \mathrm{PO} \mathrm{qDay);} \mathrm{K2} \mathrm{was} \mathrm{positive} \mathrm{control} \mathrm{group}$ (those given $20 \%$ fructose $1,86 \mathrm{~g} / \mathrm{kg} \mathrm{BW} P O$ qDay and standard insulin resistance therapy metformin $500 \mathrm{mg} / \mathrm{kg} \mathrm{BW} \mathrm{PO}$ $q$ Day); the K3 treatment group was given $20 \%$ fructose $1,86 \mathrm{~g} / \mathrm{kg} \mathrm{BW} \mathrm{PO} \mathrm{qDay} \mathrm{and} \mathrm{celery} \mathrm{extract} 200 \mathrm{mg} / \mathrm{kg} \mathrm{BW} P O \mathrm{qDay} ;$ the K4 treatment group was given fructose 20\% 1,86 mg/kg BW PO qDay and celery extract $400 \mathrm{mg} / \mathrm{kg} \mathrm{BW} \mathrm{PO} \mathrm{qDay;} \mathrm{and} \mathrm{the} \mathrm{K5}$ treatment group was given fructose $20 \% 1,86 \mathrm{mg} / \mathrm{kg} \mathrm{BW} \mathrm{PO} \mathrm{qDay} \mathrm{and} \mathrm{celery} \mathrm{extract} 600 \mathrm{mg} / \mathrm{kg} \mathrm{BW} \mathrm{PO} \mathrm{qDay.} \mathrm{The} \mathrm{treatment}$ had been given every day for 60 days. Fasting blood glucose levels were measured using a Glucometer. Fasting blood insulin levels were measured using ELISA, HOMA-IR was calculated using a standardized formula, and GLUT4 protein expression was measured using immunohistochemistry. It the end of the intervention, there was a significant decreased in fasting blood glucose $(F B G)$ in K4 group compared with K1 ( $p<0.05)$, insulin resistance in K1 was characterized by a higher HOMA-IR value compared to the therapy group, especially K4 and K5 $(p<0.05)$. There was an increase in GLUT-4 expression on K4 and $K 5$ compared with $K 1(p<0.05)$. It can be concluded that celery extract has antihyperglycemia effect and furthermore it can prevent insulin resistance condition.
\end{abstract}

Keywords: Diabetes mellitus; celery extract; rat

\section{ABSTRAK}

Diabetes melitus (DM) merupakan salah satu dari masalah kesehatan global dan menempati peringkat ke-4 penyebab utama kematian di negara berkembang. Patogenesis DM meliputi abnormalitas pada sekresi insulin dan aktivitas insulin terhadap target organ yang disebut sebagai resistensi insulin Penelitian ini bertujuan menelaah khasiat seledri (Apium graveolens) sebagai pencegahan terhadap resistensi insulin. Penelitian ini menggunakan sampel tikus strain Wistar (Rattus norvegicus) sebanyak 45 ekor, jantan, usia 4-6 minggu, berat badan 150-175 gram, dan memiliki GDP normal. Kelompok sampel dibagi menjadi 5 kelompok yaitu K1 (Fruktosa 20\% p.o 1,86 mg/kgBB/hari), K2 (Fruktosa 20\% p.o 1,86 mg/kgBB/hari dan Metformin $500 \mathrm{mg} / \mathrm{kgBB} / \mathrm{hari}$ ), K3 (Fruktosa 20\% p.o 1,86 mg/kgBB/hari dan Ekstrak Seledri p.o $200 \mathrm{mg} / \mathrm{kgBB} / \mathrm{hari}$ ), K4 (Fruktosa 20\% p.o 1,86 mg/kgBB/hari dan Ekstrak Seledri p.o $400 \mathrm{mg} / \mathrm{kgBB} /$ hari), dan K5 (Fruktosa 20\% p.o 1,86 mg/kgBB/hari dan Ekstrak Seledri p.o $600 \mathrm{mg} / \mathrm{kgBB} / \mathrm{hari}$ ). Perlakuan diberikan setiap hari selama 60 hari. Kadar Glukosa darah puasa diukur menggunakan Glukometer. Kadar Insulin darah puasa diukur menggunakan ELISA, HOMA-IR dihitung menggunakan rumus yang sudah terstandarisasi, serta ekspresi protein GLUT4 diukur menggunakan imunohistokimia. Pada akhir perlakuan terdapat penurunan gula darah puasa yang signifikan pada K4 dibandingkan dengan $K 1(p<0.05)$, terjadi resistensi insulin pada K1 ditandai dengan nilai HOMA-IR yang lebih tinggi dibandingkan dengan kelompok terapi terutama dengan K4 dan K5 $(p<0.05)$. Terjadi peningkatan ekspresi GLUT-4 pada K4 dan K5 dibandingkan dengan K1 ( $p<0.00)$. Dapat disimpulkan bahwa ekstrak seledri memiliki efek antihiperglikemia dan dapat mencegah resistensi insulin.

Kata kunci: Diabetes melitus; ekstrak seledri; tikus

Correspondence: Purwo Sri Rejeki, Department of Physiology, Faculty of Medicine, Universitas Airlangga, Jalan Prof Dr Moestopo No. 47, Surabaya, Indonesia. E-mail: purwo_faal@yahoo.com

pISSN:2355-8393 • eISSN: 2599-056x • doi: http://dx.doi.org/10.20473/fmi.v56i4.23411

- Fol Med Indones. 2020;56:269-274 • Received 1 May 2019 • Accepted 14 Nov 2019

- Open access under CC-BY-NC-SA license • Available at https://e-journal.unair.ac.id/FMI/ 


\section{INTRODUCTION}

Today, diabetes mellitus (DM) is one of the global health problems and major cause of death in most countries in the world. Diabetes Mellitus affects many people in the world and in the top 4th ranks as the main cause of death in developing countries. IDF data in 2015 stated that DM patients worldwide reached 415 millions (IDF, 2015). Diabetes Mellitus is classified as type I Diabetes Mellitus (type I DM) and type II Diabetes Mellitus (type II DM). Type II DM is $90 \%$ of all diabetes that increases as the result of lifestyle changes (Indonesian Ministry of Health, 2014). The incidence of DM is 1 of 11 adults worldwide and estimated in 2040 there will be 1 of 10 adults suffer from DM. China is the country with the largest DM population, while Indonesia is ranked 7th with DM population as many as 10 million (IDF, 2015). According to data from Indonesian health ministry showed that amount of DM patients aged, 15 years in Indonesia was 12 million people, and glucose intolerance patients was 52 million people. East Java had the largest population diagnosed with DM amount 605,974 people of total $28,855,895$ people aged $>15$ years (Indonesian Ministry of Health 2014).

The pathogenesis of type II DM involves abnormalities in insulin secretion and activity. In addition, the failure of pancreatic $\sqrt{ } \ddot{u}$ cell function which ultimately also relates to insulin secretion abnormalities, resulted in resistance of cells effector and target tissue to insulin is the main pathophysiology of type II DM (Saini, 2010). Insulin resistance is a condition when normal insulin concentration cannot produce a normal cellular biological response, especially in muscle cells, liver cells and fat cells, so that a higher insulin level is needed to become normoglycemia (Baynes \& Dominiczak 2014).

Prevention of insulin resistance is expected to reduce the incidence of chronic diseases that have high morbidity and mortality (Weickert 2012). Today, the consumption of traditional or herbal medicines for the prevention and treatment of illnesses is widely used. Consumption of traditional medicines or herbs has been widely accepted in many countries of the world, their use has been utilized in health services, especially in the primary health services (Indonesian Ministry of Health 2007). This fact stimulates interesting and curiosity of researchers to utilize the abundant natural plant resources in Indonesia as an herbal source to prevent insulin resistance, one of them is celery (Apium graveolens).
Celery is one of the vegetable commodities that is widely used as a flavoring and decorating dish. Celery seed oil extract is used as medicine. The entire component of celery includes stems, roots and leaves whose many useful active compounds (Balitsa 2008). Celery extract contains 30 types bioactive compounds (Anggraeni et al 2016). One of the active component is apigenin which is belongs to flavonoid compound and has an important role in the therapeutic efficacy properties of celery extract. Apigenin in celery can stimulates insulin secretion whose function in lowering blood glucose (Kooti et al 2015, Jung et al 2016) Apigenin also effective in condition of dyslipidemia, liver steatosis, and hepatomegaly (Jung et al 2016).

Celery extract also contains rich flavonoids compound such as apigenin, apiin, cumarine, quercetin, and also contains antioxidant such as vitamins $\mathrm{E}$ and vitamin $\mathrm{C}$ (Kooti et al 2015). Various studies were conducted to assess the antioxidant activity of celery, which includes the roots, stems, leaves and seeds. Antioxidant activity of Celery showed a good progress of lipid peroxidation by decreasing Malondialdehyde (MDA) levels and increasing activity of antioxidant enzymes, such as catalase (CAT), superoxide dismutase (SOD), glutathione (GSH) transferase. In addition, celery extracts also showed improvements in blood glucose levels in diabetic mouse models (Al-Sa'aidi et al 2012).

No previous conducted research has discussed about the effect of celery extract in preventing insulin resistance. This research will assess fasting blood glucose (FBG) level, HOMA-IR and GLUT-4 expression in the skeletal muscle of fructose induced insulin resistance rat (Rattus norvegicus) to study the effect of celery extract in preventing insulin resistance.

\section{MATERIALS AND METHODS}

The study was conducted from August to October 2018, and has passed the ethical clearance which number is 21/EC/KEPK/FKUA/2019. This study was a true experimental laboratories study using a randomized post-test only control group design. In this study, experimental animals were divided into 5 treatment groups, K1 was negative control group (insulin resistance by given $20 \%$ fructose $1.86 \mathrm{~g} / \mathrm{kg} \mathrm{BW}$ PO qDay); K2 was positive control group (those given 20\% fructose $1,86 \mathrm{~g} / \mathrm{kg}$ BW PO qDay and standard insulin resistance therapy metformin $500 \mathrm{mg} / \mathrm{kg}$ BW PO qDay); the K3 treatment group was given $20 \%$ fructose 1,86 $\mathrm{g} / \mathrm{kg}$ BW PO qDay and celery extract $200 \mathrm{mg} / \mathrm{kg} \mathrm{BW}$ PO qDay; the K4 treatment group was given fructose $20 \% 1,86 \mathrm{mg} / \mathrm{kg}$ BW PO qDay and celery extract 400 
$\mathrm{mg} / \mathrm{kg}$ BW PO qDay; and the K5 treatment group was given fructose $20 \% 1,86 \mathrm{mg} / \mathrm{kg}$ BW PO qDay and celery extract $600 \mathrm{mg} / \mathrm{kg}$ BW PO qDay. The treatment had been given every day for 60 days.

Wistar rats (Rattus norvegicus) obtained from the Experimental Animal Unit of the Biochemistry Laboratory, Faculty of Medicine, Airlangga University. The inclusion criterias of the samples were male sex, aged 4-6 weeks, weight 150-175 grams, overall in healthy condition, and had normal fasting blood glucose levels by tested before treatment. The average normal fasting blood glucose level of white rats was 111.6 $\mathrm{mg} / \mathrm{dL}$ (Wang et al., 2010).

Rats were induced by administering $20 \%$ fructose solution orally at a dose of 1.86 grams $/ \mathrm{kg}$ body weight since day 1 until day 60 days which is expected to induce insulin resistance (Wulansari 2017). Celery extract is also given orally on day 1 until day 60 in adjusted dose of treatment. After giving the treatment for 60 days, rats were fasted overnight (10 hours) then terminated by taken intracardiac blood samples then the serum was examined to assess fasting insulin. Thigh (gastrocnemius) muscle tissue also toke to analyze GLUT-4 expression by immunochemistry examination.

\section{Rat fasting blood glucose (FBG) level measurement (Rattus norvegicus)}

Fasting blood glucose levels were measured before giving a high-fructose diet (before treatment) to ensure that it was not in a condition of hypoglycemia or hyperglycemia. Fasting blood glucose level examination after treatment (post-test) was carried out at the end of the study before rats were terminated on day 60 using glucometers.

\section{Calculation of HOMA-IR}

HOMA-IR were obtained from fasting insulin with fasting blood sugar. The HOMA-IR formula: Fasting insulin $(\mu \mathrm{IU} / \mathrm{mL}) \mathrm{x}$ fasting blood glucose $(\mathrm{mmol} / \mathrm{L}) / 22.5$ $(\mathrm{Qu}$ et al., 2011). Calculation of HOMA-IR in determining insulin resistance in Wistar rats has been validated by several studies (Antunes et al 2016, Mather 2009)

\section{Retrieval of rat skeletal muscle tissue (Rattus norvegicus)}

Retrieval of skeletal muscle tissue was carried out in the gastro-cervical section in each group of mice at the end of the study. The tissue then fixed by $10 \%$ neutral buffer formalin for making histopathological and immunohistochemical preparations in skeletal muscle tissue of rat (Rattus norvegicus). The skeletal muscle tissue of the rat after fixation process then processed through stages of dehydration, clearing, impregnation, embedding. Embedding was done by paraffin method. Skeletal muscle tissue of rats was cut used 4-5 $\neg \mu \mathrm{m}$ microtome and placed on a object glass then was smeared with lysine. The object glass was placed in a warm place for 15 minutes so that the tissue pieces was more attached and ready to be analyzed. To analyze morphology of muscle tissue, routine coloring was needed using reagent HE. The initial stage of tissue staining was deparafination (paraffin removal), carried out by aquadest washing on pieces of tissue. A piece of tissue was drained of water then placed in haematoxyllin for 5 minutes after which it was rinsed with running water. The tissue pieces then colored by soaking in lithium carbonate and rinsing with running water. because it is able to recognize several epitopes and cross reactivity can occur (Konrad et al., 2002; Wulansari, 2017). pieces are placed in $1 \%$ alcoholic acid for a few seconds before rinsing again with running water and soaked in eosin for 5 minutes. After rinsing with running water, dehydrating and cleaning, the preparation is ready for use. Histopathological preparations consisted of 3 slides per treatment sample. The indirect immunohistochemical staining procedure is carried out by deparafination after being given GLUT-4 Primary polyclonal antibody then washed with PBS 3 times every 2 minutes. Then the enzyme labeled secondary antibody was given using biotin-streptavidin or biotin avidin. Washed again with PBS 3 times every 2 minutes. Then given the chromogen substrate DAB (3,3-diaminobenzidine) for 5 minutes. Washed again with PBS 3 times every 2 minutes then rinsed with aquadestilata. Then put in Mayer's hematoksilin for 6 minutes and washed with running water, dehydrated, cleared, mounted.

Immunohistochemical staining procedures using polyclonal antibodies on GLUT-4 examination have been widely used in previous studies. This procedure has the advantage of being more economical and easy to obtain and has high affinity which results in sharp coloring but less specificity compared to monoclonal antibodies.

\section{RESULTS}

Total 45 rats were analyzed after experimental procedure. The mean of fasting blood glucose (FBG) in $\mathrm{K} 1$ was the highest $(130.50 \pm 17.14 \mathrm{mg} / \mathrm{dL})$ compared with another group and the lowest FBG was in K4 $(78.00 \pm 12.64 \mathrm{mg} / \mathrm{dL})$. The highest HOMA IR was in $\mathrm{K} 1(0.06 \pm 0.02)$ and the lowest was in K4 $(0.042 \pm 0.01)$.

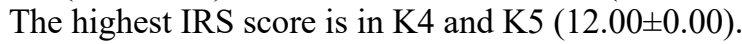


Table 1. Effect of celery extract (Apium graveolens) on FBG, HOMA-IR and IRS (the present of GLUT-4 in rat skeletal muscle)

\begin{tabular}{lccccc}
\hline \multicolumn{1}{c}{ Research Data } & $\begin{array}{c}\mathrm{K} 1 \\
(\mathrm{n}=8)\end{array}$ & $\begin{array}{c}\mathrm{K} 2 \\
(\mathrm{n}=7)\end{array}$ & $\begin{array}{c}\mathrm{K} 3 \\
(\mathrm{n}=8)\end{array}$ & $\begin{array}{c}\mathrm{K} 4 \\
(\mathrm{n}=8)\end{array}$ & $\begin{array}{c}\mathrm{K} 5 \\
(\mathrm{n}=9)\end{array}$ \\
\hline $\begin{array}{l}\text { FBG post- } \\
\text { treatment }(\mathrm{mg} / \mathrm{dL})\end{array}$ & $130.50 \pm 17.14^{\mathrm{A}}$ & $95.14 \pm 10.37^{\mathrm{B}}$ & $100.00 \pm 10.54^{\mathrm{B}}$ & $78.00 \pm 12.64^{\mathrm{C}}$ & $91.22 \pm 11.19^{\mathrm{B}}$ \\
HOMA IR (\%) & $0.06 \pm 0.02^{\mathrm{A}}$ & $0.05 \pm 0.01^{\mathrm{A}}$ & $0.05 \pm 0.01^{\mathrm{A}}$ & $0.04 \pm 0.01^{\mathrm{B}}$ & $0.04 \pm 0.01^{\mathrm{B}}$ \\
IRS (score) & $2.00 \pm 0.00^{\mathrm{A}}$ & $5.71 \pm 0.76^{\mathrm{B}}$ & $7.50 \pm 2.78^{\mathrm{B}}$ & $12.00 \pm 0.00^{\mathrm{C}}$ & $12.00 \pm 0.00^{\mathrm{C}}$ \\
\hline
\end{tabular}
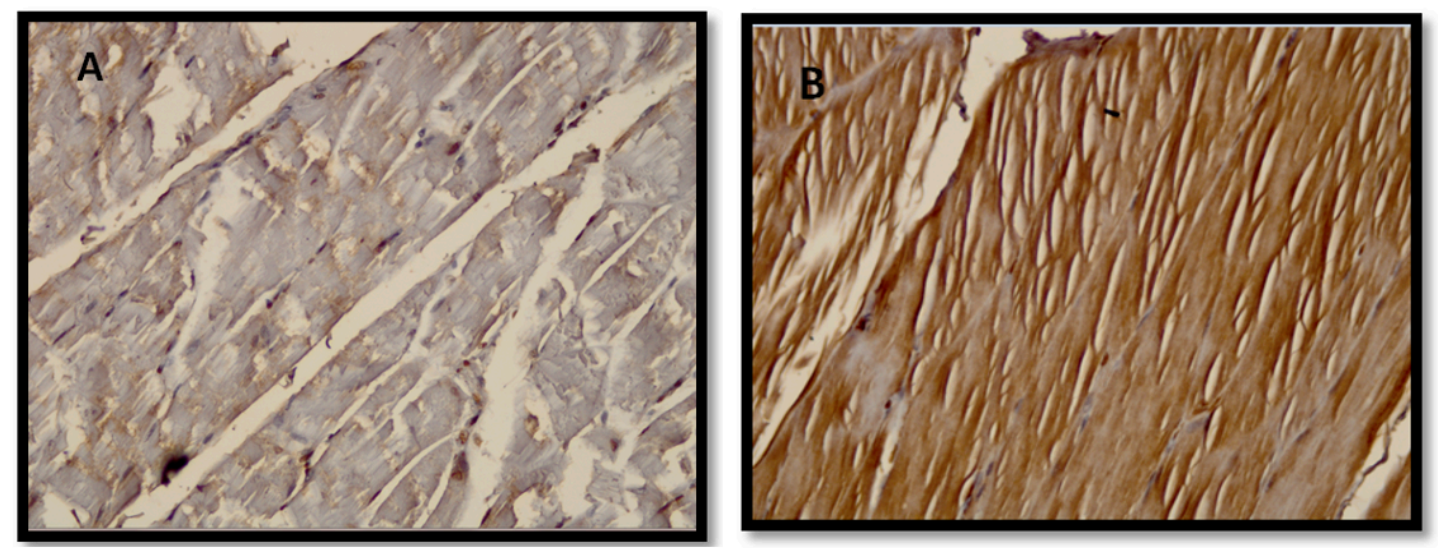

Fig. 1. The difference of IHC by GLUT-4 antibody appearance in non-treated group (picture A) showed 50\% GLUT-4 express in cytoplasm (score 2) low intensity of color (score 1); and in $400 \mathrm{mg} / \mathrm{dL}$ celery extract treated group (picture B) showed 90\% GLUT-4 express in skeletal cell cytoplasm (score 4) high intensity of color (score 3) objective lens 400x.

Numbers represent mean \pm SD. Different superscript letters represent the presence of significances between groups $(p<0.05) . \quad \mathrm{K} 1$ : insulin-resistance (negative) control group, K2: positive control group treated with metformin, K3: group treated with celery extract 200 $\mathrm{mg} / \mathrm{kg}$ BW PO qDay, K4: group treated with celery extract $400 \mathrm{mg} / \mathrm{kg}$ BW PO qDay insulin, K5: group treated with celery extract $600 \mathrm{mg} / \mathrm{kg}$ BW PO qDay.

\section{DISCUSSION}

\section{The effect of celery extract on FBG}

Based on the result of fasting blood glucose (FBG) levels, there was significant differences of FBG after intervention in groups $\mathrm{K} 1, \mathrm{~K} 3$ and $\mathrm{K} 5$. This data proves that the high fructose diet was succeed to produce hyperglycemia in animals model. Untreated group was experienced a very significant increase in FBG compared to other groups, while there was decreasing in post treatment FBG in $400 \mathrm{mg} / \mathrm{dL}$ celery extract treated group (K4). This result was different from previous studies conducted by Harvi and Doss (2012) which stated that the higher the celery dose, the lower the blood sugar levels in experimental animals. A dose of $400 \mathrm{mg} / \mathrm{dL}$ celery in K4 was an effective dose to treated hiperglycemia in animal models. According to research conducted by Al-Sa and Al-Shihmani (2013), the differences in glucose levels in rats given celery extract which compared to untreated group were caused by the effects of n-butanol fraction of celery on metabolic processes, that increased insulin levels and increased glucose utilitation by body cells. Another study by Marles and Fransworth 1996 found that the active component in celery extract was cumarine which has potentiation of lowering blood sugar levels and increasing body weight. The latest research states that the anti-hyperglycemic effect of celery extract could be used safely. There were anti-hyperglycemic effects of celery extract that mediated by insulin released from beta cells. The use of celery extract in the right dosage was also declared safe by previous studies by Ismael (2011), Al-Shwilly (2011), and Al-Sa'aidi et al (2012). Decreasing glucose levels after 2 weeks of therapy may be caused by decrease of gluconeogenesis in hepatic, insulin levels would significantly increase after 35 days of celery extract therapy. 
Celery also contained flavonoids which was one of the largest components of phenol found in plants. These flavonoids were thought to be involved in the healing process of several diseases that caused by free radicals such as diabetes melitus. Celery contains several flavonoids such as apigenin and luteolin. Apigenin functions was to inhibit enzin aldolase reductase which plays role in polyol pathways by catalyzing the reduction reaction of glucose to sorbitol, this sorbitol cannot escape from the cell membrane. In diabetic conditions, sorbitol accumulation results in chronic complications of diabetes, such as neuropathy, retinopathy, and cataracts (Niaz et al 2013).

In diabetic rats treated with celery extract, decrease in blood sugar levels caused by secretion of insulin originating from B cells, but in this study there was no significant difference in the level of insulin among the treatment groups. The second possibility was increasing glucose transport into cells and increasing glycogen formation in the liver (Niaz et al 2013)

\section{The effect of celery extract on HOMA-IR}

Based on the test of the average HOMA IR difference there was a significant difference between the HOMA IR values in the negative control group (K1) compared to the other treated groups, especially $\mathrm{K} 4$ and $\mathrm{K} 5$. This indicates that there was insulin resistance in the negative control because no intervention has been carried out.

\section{Effect of celery extract on GLUT-4 expression in rat skeletal muscle (IRS)}

GLUT 4 expression was assessed by the IRS. The highest IRS value was obtained in $400 \mathrm{mg} / \mathrm{dL}$ (K4) and $600 \mathrm{mg} / \mathrm{dL}(\mathrm{k} 5)$ treated groups. This indicates that the higher the celery dose, the higher the expression of GLUT 4. Study conducted by Yusni et al (2018) showed that celery extract containing Quercetin which plays an important role in decreasing blood sugar on diabetic mice induced by Alloxan. Quercetin was identified not only to play role in the translocation of GLUT- 4 mRNA into adipose cell membranes and skeletal cells but also could upregulate GLUT-4. Quercetin and naringenin mRNA levels play role in protecting Beta cells against toxic cytokine via phosphatidylinositol 3-kinase (PI3K). Quercetin could reduce blood sugar levels through GLUT-4 which had same effect through gluconeogenesis and glycogenolysis in the liver, and stimulated insulin secretion by beta pancreaticus cells. Celery extract also contains phenolic compounds which were known to increase glucose uptake and increase GLUT-4 expression. Luteolin has been studied previously to potentially improve insulin action and stimulate GLUT-4 activity in diabetic rats as well as increasing antioxidant levels in diabetic nephropathy mice. These antioxidants increase insulin secretion through nuclear factor kappa beta (NF-kB) signaling pathway and iNOS-NO (Yusni et al., 2018).

\section{CONCLUSION}

Celery extract is antihyperglycemic potent that had many effect in lowering blood sugar levels. Celery, which consist of antioxidant, can be used as preventive agent for non-communicable disease such as DM. Futher research must be conducted to produce selective active component of celery that can be consumed for human safely.

\section{ACKNOWLEDGMENT}

This research is not has conflict of interest. Thank you for Animal laboratory, Biochemistry Department of Universitas Airlangga, Physiology Department of Universitas Airlangga, and other lecturer that help me to conduct this study.

\section{REFERENCES}

Al-Sa'aidi A (2012). Antioxidant activity of n-butanol extract of celery (Apium graveolens) seed in streptozotocin-induced diabetic male rats. Research in Pharmaceutical Biotechnology 4, 24-29. doi: 10.5897/RPB12.002.

Al-sa JAA, Al-shihmani BAK (2013). Antihyperglycaemic and pancreatic regenerative effect of n-butanol extract of celery (Apium graveolens) seed in STZ- induced diabetic male rats

Anggraeni T, Ridwan A, Kodariah L (2016). Ekstrak etanol seledri (Apium graveolens) sebagai antiatherogenik pada tikus (Rattus norvegicus) yang diinduksi hyperlipidemia. Prosiding Symbion, 171188

Antunes LC, Jessica LE, Manoela NJ, et al (2016). Validation of HOMA-IR in a model of insulinresistance induced by a high-fat diet in Wistar rats. Archieves of Endocrinology and Metabolism. 60, 138-42. doi: 10.1590/2359-3997000000169

Balitsa 2008. Petunjuk teknis budidaya seledri. ISO 9001: 2008. Bandung, Balai Penelitian Tanaman Sayuran

Baynes JW, Marek HD (2014). Medical biochemistry 4th ed. Elsevier, 264-283

Harvi VD, Doss DVA (2012). Anti-lipidemic effect of Apium graveolens and Cymbopogan flexuous in 
Diabetic Rats. International Journal of Current Research 4, 11-12

Indonesian Ministry of Health (2007). Kebijakan obat tradisional nasional. Keputusan Menteri Kesehatan Republik Indonesia Nomor: 381/Menkes/SK/III/2007. Jakarta, Departemen Kesehatan Republik Indonesia

Indonesian Ministry of Health (2014). Situasi dan analisis diabetes. Jakarta, Departemen Kesehatan Republik Indonesia

Ismael AK (2011). Antioxidant and hypolipidemic effects of $\mathrm{n}$-butanol fraction of celery (Apium graveolens) seed extract in intact and STZ-induced diabetic mature male rats. Research in Pharmaceutical Biotechnology 4, 24-29. DOI: 10.5897/RPB12.002

Jung UJ, Yun YC, Myung SC (2016). Apigenin ameliorates dyslipidemia, hepatic steatosis and insulin resistance by modulating metabolic and transcriptional profiles in the liver of high-fat dietinduced obese mice. Nutrients 8, pii: E305. doi: 10.3390/nu8050305

Konrad D, Philip JB, Zafar N, et al (2002). Need for GLUT4 activation to reach maximum effect of insulin-mediated glucose uptake in brown adipocytes isolated from GLUT4myc-expressing mice. Diabetes Journals 51, 2719-2726. doi.org/10.2337/diabetes.51.9.2719

Kooti W, Sara AA, Majid AS, et al (2015). A review on medicinal plant of Apium graveolens, Advanced Herbal Medicine 1, 48-59

Mather K (2009). Surrogate measures of insulin resistance: of rats, mice, and men. American Journal of Physiology-Endocrinology and Metabolism 296, E398-399. doi:10.1152/ajpendo.90889.2008

Niaz K, Gull S, Zia MA (2013). Antihyperglycemic/hypoglycemic effect of celery seeds (ajwain/ajmod) in streptozotocin induced diabetic rats. Journal of Rawalpindi Medical College $17,134-137$

Qu HQ, Quan L, Anne RR, et al (2011). The definition of insulin resistance using HOMA-IR for Americans of Mexican descent using machine learning. PLoS One 6. doi: 10.1371/journal.pone.0021041

Saini V (2010). Molecular mechanisms of insulin resistance in type 2 diabetes mellitus. World Journal of Diabetes 1, 68-75. doi: 10.4239/wjd.v1.i3.68

Wang Z, Yang Y, Xiang X, et al (2010). Estimation of the normal range of blood glucose in rats. Wei Sheng Yan Jiu 39, 133-7

Weickert MO (2012). What dietary modification best improves insulin sensitivity and why? Clinical Endocrinology 77, 508-12. doi: 10.1111/j.13652265.2012.04450.x

Wulansari DD, Achmad B, Suhartatik (2017). Effect of papaya seed extract (Carica papaya Linn.) on glucose transporter 4 (GLUT 4) expression of skeletal muscle tissue in diabetic mouse induced by high fructose diet. Traditional Medicine Journal 22, 131-138

Yusni Y, et al (2018). The effects of celery leaf (Apium graveolens L.) treatment on blood glucose and insulin levels in elderly pre-diabetics, Saudi Medical Journal 39, 154-160. doi: $10.15537 / \mathrm{smj} .2018 .2 .21238$ 